\title{
AN ACTIVE LEARNING PEDAGOGY FOR INTERNATIONAL MANAGEMENT: CASES IN GERMANY, MEXICO, AND ETHIOPIA
}

\author{
William David BRICE ${ }^{1}$ \\ Jim KATZENSTEIN ${ }^{2}$ \\ ${ }^{1}$ College of Business Administration and Public Policy, California State University Dominguez Hills \\ ${ }^{2}$ College of Business Administration and Public Policy, California State University Dominguez Hills \\ (C) 2016 William David Brice,Jim Katzenstein \\ This is an open access article distributed under the Creative Commons Attribution-NonCommercial-NoDerivs license \\ (http://creativecommons.org/licenses/by-nc-nd/3.0/) \\ DOI: 10.1515/eras-2016-0008
}

\begin{abstract}
Three very different study abroad visits for US students illustrate limitations of short-term study abroad experiences as well as highlight successful approaches. Lessons can be gained for strategically planning experiences that gain the most cross-cultural learning from short study abroad visits.

Seven US business students attended a two-week business-plan competition in Germany that involved students from six countries. Incidents occurred which could have provided critical cross-cultural learning. Facultyassisted analysis of these cultural incidents could have been used as teachable moments.

Thirty US business students attended a one-week study visit to Mexico in conjunction with a Mexican university. The students attended economic lectures at the university and visited industrial locations. Students were allowed to do as they wished during free time, without any interaction with host nationals or assisted cultural analysis.

Two US business students journeyed to Ethiopia for a three week visit in conjunction with an Ethiopian business college. The students were involved with in-depth cultural research and intensive interaction with host nationals. Strong gains in cultural understanding were observable.

The thesis of this pedagogical case study is that instructors and program directors should seize upon, and create, the opportunity for unplanned critical incidents. These incidents should not be looked on as problems, difficulties, or bad behavior, but as normal cross-cultural interactions that can teach students more than preplanned program interactions. Intensive interactions with host nationals in uncontrolled situations, combined with expert analysis, may convey greater cross-cultural learning than controlled formal programs.
\end{abstract}

.Keywords: cross-cultural, study abroad, US students, Mexico, Germany, Ethiopia.

\section{INTRODUCTION}

Only 3\% of American undergraduates study abroad in any year (Holland and Kedia, 2003), about 250,000 total with around $18 \%$ being business students (Bhandari and Chow, 2007). Almost half of freshman students state an interest in studying abroad and 75 percent of adults believe students should study overseas for some period of time (Holland and Kedia, 2003). However, about half of college students think they don't have enough time or money to study abroad (Albers-Miller, Prenshaw, and Straughan, 1999). This being the case, short-term overseas travel programs are especially suitable for a great many college students.

Research literature almost universally praises the benefits of study abroad. Schuster et al. (1998) states that students need to personally experience foreign countries to understand them. Clarke et al. (2009) empirically showed that students who studied abroad gained higher levels of intercultural ability and became more globally aware. Erffmeyer and Al-Khatib (1997) state that study abroad students had higher levels of political and cultural 
understanding. Students who studied overseas had a higher graduation rate (Ingraham, 2003).

There are only a small number of study abroad studies (Gillespie, 2002), Nonquantitative literature has mostly focused on study abroad logistics and not on educational content (Clarke et al., 2009). Orvis and Wajda (2008) state that study abroad has greater impact if students can go beyond classroom teaching. Williams (2005) states that studyabroad programs in and of themselves are not adequate but combining direct cross-cultural interaction will maximize intercultural communication learning. Study abroad students that interacted directly with host nationals made the greatest gains in cross-cultural knowledge and expressed the most satisfaction with the international experience (Rohrlich and Martin, 1991). Real-life cultural immersion incidents, with faculty directed analysis, will enhance international student programs along with the usual visits, seminars, and other constructed student activities (Brice, 2012) (Brislin and Yoshida, 1994).

This is a pedagogical case study comparing three summer abroad programs and is not meant to be taken as an empirical research paper. Furthermore, these examples are of American faculty taking American students to foreign countries. Reverse examples would be interesting but would not add useful balance. Faculty of any culture might appreciate the points made here. An exhaustive listing of issues arising out of a large number of student trips abroad would also certainly be useful, however, the idiosyncratic nature of such a large number of cross-cultural interactions might obscure the central thesis of this essay: that instructors and program directors should create the opportunity for students to experience and analyze unplanned critical incidents, not as problems, difficulties, or bad behavior, but as normal cross-cultural interactions that can teach as much or more than programmed interactions.

\section{MEXICO: LARGE-GROUP SHORT-TERM STUDY}

Three business professors from the University of Arkansas at Little Rock (UALR) accompanied thirty students for a one week study visit to Mexico. The first two days were spent at a Lake Chapala hotel resort owned and run by the University of Guadalajara while the remainder of the visit was spent in Guadalajara. The students attended specially arraigned economic seminar lectures at the University of Guadalajara and visited a number of industrial and business locations including bread, soap, beer, and tequila factories. The students during free time, without accompaniment by faculty or host nationals, were allowed to do as they wished, first in the small Lake Chapala village of Ajijic and then in the big city of Guadalajara. There was no attempt by faculty to assist students in cross-cultural analysis of these experiances.

During official seminar and industry visits, the thirty US students traveled together on the same bus and were only accompanied by their three professors and one guide. No Mexican students or other host nationals interacted with them on a one-to-one basis. During daytime meals in restaurants, the students invariably chose to sit in one or two large groups together whenever possible. It could be clearly discerned that during these times, when sitting in entirely authentic Mexican restaurants surrounded by Mexicans and their families, these Arkansas students were intensely focused on conversing with each other. They were entirely oblivious to the fact that they were louder then anyone else and that they were stared at by most of the other restaurant patrons, often in an unfriendly way.

In the evening, many of the students went shopping and had dinner in American restaurants such as the Hard Rock Cafe or Pizza Hut. Many of the male students visited bars and nightclubs. In all cases the students stayed in fairly large and conspicuous groups, attracting negative attention; and in a couple of cases narrowly avoiding altercations with 
young Mexican males. It became apparent that going out drinking was the high point of the trip for many if not most of the students. This trip has been conducted yearly for some time and has a reputation among UALR business students as a drinking trip. It is doubtful that any significant cross-cultural learning greater than that gained by the average tourist took place.

\section{GERMANY: A PEDAGOGY OF CRITICAL INCIDENTS}

Five American students from the University of Arkansas at Little Rock (UALR), two students from Midwestern State University in Wichita Falls Texas, along with two accompanying faculty members and the Dean of the UALR College of Business, attended a two-week summer program in Germany hosted by Erfurt University. The program involved small numbers of students from institutions in the US, UK, India, Indonesia, Russia, Germany, and a few other locations. They were grouped in multi-cultural teams and taken through the process of creating competing business plans. At the end of the program, a winning business plan was chosen by the faculty. The program included lectures given by the German hosts and visiting faculty. German business students were on hand daily to act as guides and councilors for the foreign students. The group work, of course, afforded excellent opportunities to directly experience the issues of working cross-culturally. During the two weeks, all the students resided at the same Youth Hostel and took a number of field trips together to visit business firms and cultural destinations. This, along with their various experiences during free time, afforded additional experience with German culture. Although a great deal of cultural learning took place through the organized efforts of the German hosts, the most important learning opportunities occurred when unforeseen problems or critical issues arose. A number of typical student abroad incidents took place on this trip which, with proper analysis and faculty assistance, could have provided just such learning.

These incidents cannot be simply explained away by bad behavior. It should be assumed that all participants in this program behaved in a manner that was normal and typical for their cultural backgrounds. If learning about cultural differences and issues is the purpose of taking students abroad, then it would be counterproductive to somehow train American students to act French in France and German in Germany in order to have a smooth visit. In addition, to intentionally create an experience abroad that provides no difficulty for students would be to minimize all possibility of actual cross-cultural learning. Although it is always nice to make a good impression, that is not the primary purpose of an overseas student trip.

It must be noted that the Erfurt University program directors and the visiting international faculty may have different motivations. Faculty who bring their students abroad generally are seeking to provoke experiential cross-cultural learning in their students while program directors have the additional motivation of running a smooth program and making a good show of it. Bureaucratic and career motivations may make program directors unreceptive to unplanned critical incidents, especially any that may look like a "problem". On the other hand, astute directors may find that by treating these incidents as "normal" learning opportunities, which can be analyzed in the classroom, they can defuse what might otherwise be seen as embarrassing and threatening problems. The incidents detailed here should be seen as just a sampling of cultural learning opportunities faculty and program directors should be on the look-out for.

The first such cultural incident during this summer program arose at the Youth Hostel, when a number of unknown students from the program repeatedly failed to wash their breakfast dishes as required by Youth Hostel rules. Some of the nations represented had reputations in Germany of being undisciplined, and some student groups were known to be of a class that commonly relied upon servants for things like washing dishes. Although there was 
much supposition by various groups about which other group must be responsible, the culprits were never unmasked. The young men and women who kept the German Hostel were not amused and made a formal and emotional complaint to the German program head. The German student guides were also not amused and made many comments backing up the Youth Hostel workers. The Youth Hostel imposed collective punishment upon the entire summer program contingent by denying all fifty of them access to any further breakfast or access to the kitchen. This hurt the students from poor countries much more than those from rich areas who could easily afford to eat at cafes. This would mean that the logical culprits were not disadvantaged while those who had washed their dishes were. The German program head subsequently made a detailed and somewhat emotional lecture on responsibility to the assembled program participants igniting some dissention among the students. Students from the US and UK particularly did not think it was fair to punish everyone for the failure of a few students.

A second Youth Hostel incident involved an American student falling asleep on a Hostel living room couch in a common area. The supposition was that the student must have been drunk and irresponsible. The same American student soon after became noticeably ill with flu and missed several program sessions. Despite this, he managed to provide critical content to his group's winning business plan. Members of other nationalities also were late or missed sessions but the entire US contingent (who were from two different universities) were later classified together as a single problem by the German program organizers as if they were one irresponsible individual.

The largest issue involved a tuition give-back paid for by the German organizers. The pre-paid tuition was low to begin with (350 Euro) and 100 Euro was refunded during the middle of the program so that students would have some spending money for weekend excursions. American students, who had been told prior to the program that possibly all the tuition would be refunded, complained to the American business school Dean, who relayed the complaint along with a request for a greater give-back to the German program organizers. This provoked a significant defensive response from the German program head, who then spent much lecture time detailing the program budget and showing just how much the students were getting for such a nominal fee. This defensive response was repeated in later communications to the American Dean. An additional amount was eventually refunded at the end of the program but dispersed in differing amounts according to the distance the student had traveled to be there as well as the level of national development of their country.

A final issue concerned small student presentations national student groups had put together early in the program. Short, off-the-cuff marketing plans were thought up and presented to managers in a real German company. The student groups were asked to email their presentation materials to the company before the end of the program. One of the American groups had simply used a marker on a piece of clear plastic to draw a graph and had presented a purely fictional and impossible plan. Thus, as the plan and its materials were worthless, they did not take the request to provide the presentation materials seriously and did not provide them. The German company made repeated requests for this to the program director who made it into a somewhat major issue. Eventually, after being repeatedly ordered to comply by the American Dean, the students put something together and emailed it from the US a couple of weeks after returning home.

Such problems can be taken in at least two ways. They can be looked at as the unfortunate acts of immature students from countries that do not raise children well (the view of the German hosts) necessitating loss of face and apologies all around. This viewpoint can have unfortunate consequences for relationships between the visiting institutions and the German host college. For the hosts and faculty, even those trained in cross-cultural studies, it 
can be difficult to not react in negative ways when the organizational mechanics of the situation push them to do so. Organizational inertia would demand official reaction to complaints and other problems regardless of how cross-culturally dysfunctional such reaction might be.

Another view would be that these "embarrassing" incidents should be expected and are normal behavior by inexperienced students acting out their normal social norms in a foreign and unknown social environment. Incidents like these are very revealing. Although they cannot be manufactured, scripted or predicted with any precision, various sorts of "embarrassing" incidents are sure to arise on every student abroad experience. Astute faculty should use these incidents as invaluable teachable moments.

* First, the dish-washing issue at the Youth Hostel: The reaction from the Hostel personnel and others seemed extreme to the American and British students. Geert Hofstede (1980, 2001) scores German culture high in Uncertainty Avoidance, reflecting a German intolerance of ambiguity. Avoidance of ambiguity usually results in rules and procedures with which to make more certain that which is uncertain. German culture is very structured with "Rules" and rule-breakers are not simply short-cut takers, but may be considered "Bad" people. Rule-breaking may result in a rather emotional response that may be surprising to Americans who are from a rather low Uncertainty Avoidant culture. The US also has possibly the most individualistic culture on earth, certainly much more than Germany (Hofstede, 1991). Collective punishment was given to all the summer school participants, as the individual felons could not be identified. This collective approach resulted in lots of predictable objections from students from high individualism cultures like the US and UK.

* There are many ways of violating the rules in Germany. In gray areas, where leeway could possibly be given to a fellow German, it may not be given to a foreigner, especially a foreigner from a somewhat un-liked country. While you may not ever be able to actually point your finger at it, anti-Americanism is widespread in Germany and other Western European countries and American culture may be considered somewhat deficient in terms of politeness and sophistication (Webb, 2007). Thus, it is possible that falling asleep on the Youth Hostel couch would not mean much unless the staff was predisposed to make something out of it on the basis of nationality. In addition, the Hostel staff was young; and the young tend to be relatively high in Masculinity and not prone to tolerance. Attendance and being on time are also part of the process, as they are part of following the rules. It is well known that being precisely on time in Germany is vital; and how much worst it is to not show up at all. People from the US need to be especially blameless in these situations or else they will hold themselves up for criticism. It was very noticeable that in the emails from German faculty, the American students from both institutions were always lumped together as if they were either one individual, or else equally at fault for whatever could be said about any one individual.

* The issue of the tuition give-back by the program caused the German program director to act very defensive in the classroom. He went into great detail to defend his position. In the US a student might have just been reminded that there was no guarantee that all tuition would be reimbursed and the subject would then be dropped and forgotten; but in Germany the student complaints were taken with such great seriousness that the issue seemed to represent a kind of professional threat that had to be defended against. In a society built with so much structure and rules, i.e. High Uncertainty Avoidance (Hofstede, 1991), everyone must strongly justify themselves when challenged even a little bit. Therefore, challenges to authority in this way are as rare as they are truly serious.

* Finally, the issue of American students not turning in their company presentation: The American students thought that their presentation was a work of fiction and completely worthless to any real-life company. In addition, there would be no effect on grades if it was 
never turned in. Finally, the American student group had no official leader, and in an individualistic culture, often no one will step forward for an unofficial group without good reason. The US is a guilt society (Hofstede, (1991) and there can be no individual guilt if no individual is personally responsible. In more collective cultures, each member of any group will feel responsible to act for the group and will feel shame if the group does not do what is expected (Hofstede, (1991). Nevertheless, they were asked for the materials from the German Summer Program, who had likely promised the materials to the company. However worthless the materials might in fact be, there was a process involved. Germany has a high UAI (uncertainly avoidance index) meaning not only that there is a lot of structure and rules, but also that "Process" runs organizations (Hofstede, 1991). In the US and UK, it is the final product (the materials) that has meaning; in Germany it is the "Process". The "Process" is actually more important than any one product or result because the "Process" creates all results and without it there would be no results (in the German organizational model). Thus, it is not possible to ignore or circumvent "Process" even in small unimportant ways. Just as in the first item above, offenders may be considered to be "Bad" people deserving of an emotional response.

These types of critical incidents in cross-cultural interactions can, if properly presented as applied analysis by faculty, provide students with greater understanding of issues in international management than can be provided by carefully scripted country tours of museums and companies (Brislin and Yoshida, 1994). Although the Erfurt Summer School Program was designed by its German faculty to provide some of these types of incidents through students working with others from around the world, they obviously did not intend for cross-culture learning to take place in the ways listed here. Yet, the incidents from this list represent "real life" and learning from working in cross-cultural student groups is somewhat simulated. The proper use of non-contrived cultural immersion would enhance and complement the structured visits, seminars, and other student activities.

\section{ETHIOPIA: SMALL-GROUP FULL IMMERSION STUDENT RESEARCH}

Initial Pre-Travel State: Both students were female Americans and their pre-trip writings showed that they were especially interested in issues of women's rights and roles. The students initially stated that they thought of Ethiopia as a "traditional" country where women served their husbands by staying home and men worked. They thought women would have arranged marriages and that a dowry would be paid. Divorce would be discouraged and when there was a divorce, women might not be able to keep children afterwards. Abortion would likely be illegal. If there was education it would be men who would be encouraged to go to college and not women. Women would serve husbands by staying home. They expected that those women who were in college would have had a hard time getting there and a hard time having any career. They imagined Ethiopian students would be attracted to the Western lifestyle and luxuries but older people would not.

The students were also very concerned that the conditions of the visit would be particularly hard on them personally. They thought they might not be able to get adequate food and clean water. At the same time they worried about how to politely avoid partaking of unusual food they would be offered. They though they might have to take cold showers; that finding and using toilets would be problematic. There was a large concern about wifi internet access and being out of telephone contact with home. One student said that internet access was the main concern for her.

Another line of concern was about language, clothing and the possibility of offending host nationals through unintentional disrespect. They also anticipated some hostility or 
attempts to take advantage them as they would be seen as being 'rich' westerners.

The students also thought business would be at the flea-market family-business level with no large businesses or franchises; and that there would not be much in the way of government regulation. Transactions would probably be in trade rather than with currency. Everyone would be very poor. Few people would be able to afford to go to college and the government would be too poor to support scholarships. There would not be many universities or colleges.

Early Reactions: In the city, the students were very surprised at the widespread use of cell phones and the sight of young people dressing the same as young people do in the US. They were afraid of the driving conditions with many people riding in donkey carts and using cell phones at the same time. They noticed the visibility of the ultra poor and the affluence of professional class and how they shared the same public spaces. They ate at elite restaurants with Western-dressed rich people inside with poor streets and poor people directly outside. They found that the National Museum was in very poor shape compared with top institutions in the US. They saw large numbers of people walking long distances along the highway, often with water containers to fill in streams for their house water, and with large numbers of farm animals herded by small children at the road edge.

At the college, they were surprised at the very poor physical condition of the buildings and computer lab. They noticed the old-fashioned blackboards and lack of any technology in the classroom. The US students became increasingly frustrated at the constant interruption of electricity and internet in general and wifi in particular, at both the college and hotel. They stated that they thought this must be very hard on business and that somehow Ethiopia must have gotten "used to it".

On the other hand, they were very favorably impressed with the friendliness and intelligence of staff and students and their ability to speak in English. At this college, all instruction is in English. The American students felt like celebrities due to the attention they received.

They heard from Ethiopian students who were in the midst of taking a CSUDH online management course who said the American students in the course were a problem, as the American student groups didn't communicate well or work well together. The US students found that unlike American student groups, Ethiopian students would never divide a group project but would only do it together as a group.

In interacting with Ethiopians, the US students soon noticed that the more specific a question they asked, the more vague an answer would be given by Ethiopians. They also found that no Ethiopian student would say anything negative, especially about the government. They soon found that family is most important thing in a person's life and that divorce is very rare. They were told that peace and harmony is everyone's personal and family goal and that education is the country's most important national goal. They quickly noticed gender-based socializing and a lack of public displays of affection. The students recognized these values as being different than values in the US but attributed them to Ethiopia being a more old-fashioned Christian country.

The students were very shocked that $\$ 20$ a month is a normal wage. In the countryside they noticed widespread poverty and women doing manual labor. However, they were also surprised that electric power lines existed even in remote areas although many houses were not hooked up. They noticed significant signs of development such as the new Chinese-built freeway with some signs at the entrance written in Chinese.

Students were very much saddened by the traditional hand-made huts, manual labor, dirty and torn clothing, washing in streams from which house-hold water is obtained and walked back home, and the general non-tech way of life. They interpreted this as extreme 
poverty with people making the "best out of the situation they were living in" and compared it to the "normal" styles of living in the US. They wanted to give money to the begging children who followed them around and were only restrained by constant warnings not to do so. Although they noticed the electric power lines along the highways they thought of the many huts without connections, and the frequent power outages, as a major negative, rather than seeing the many families with power, and the long periods of the day with uninterrupted power as a big step forward.

In a visit to a student's family house in a village, they noted the single electric light. They found it difficult to accept and understand the apparent poverty of everyday people. They also found it significant and important that the men sat to talk to the guests and the women acted as traditional hosts making coffee and food. Repeatedly, the American students found it odd, old-fashioned, and illegitimate that men and women might have different roles in the home environment or anywhere else. It was important to the American students to always ask about equality in gender roles.

In all of the student's expectations and reactions, an overwhelming self-referencecriteria was apparent. Almost everything they saw or learned was related to an American interpretation and usually regarded as old-fashioned as if it were only a matter of time before the Ethiopians did things just as things were done in the US. In addition, almost everything about females in the home, school and work, was related to current American feminist ideology. In the beginning of the trip, the students could not seem to analyze Ethiopian culture in and of itself without reference to US norms. It was symbolic that when they saw the many Ethiopian bald eagles, they referred to them as American eagles.

Learning: Students began to focus on signs of change and advancement. A visit to a high-end locally-owned hotel showed them that a world-class hotel and high-level service could exist simultaneously with mud huts and donkey carts. The local clientele was obviously upper-middle to upper class. The students also met several successful entrepreneurs who were self-made and now quite rich. Views of the Chinese built freeway, railroad and factories along with a visit to a locally-owned modern water bottling plant illustrated how foreign direct investment and local business were both contributing to Ethiopia's current 8-10 percent growth rate. They heard first-hand from local businessmen that right now is a time when great success can be had in Ethiopia by those with vision, because the high growth in an undeveloped environment has created the conditions for large-scale opportunity in a multitude of areas.

They learned that the Ethiopian government will make student loans covering an entire four-year first degree to any public university student who can make high scores on a national test. Students would then pay the loans back after graduation. They encountered students who were very motivated and wanted to have more reading material.

The American students interviewed many of the Ethiopian students and found that a very large proportion were female and that they often studied technical subjects like IT and expected to work in their fields as soon as they graduated. Many of the female students dressed in Western clothing and wore makeup. They also found that Christian and Muslim students intermingled without any apparent division or discrimination.

Students in Ethiopia often wore very old and torn clothes and sandals but seemed to interact the same as American students: hanging out in groups of friends, and talking to each other during class. Wide-spread use of cell phones was a big surprise to the American students who did not think of modern technology in terms of a third world country.

Another big surprise was the Ethiopian student's obvious hunger for knowledge. They were eager to learn, and many came from far away to attend school. Succeeding in education is an absolute must for them, unlike the common casual attitude in the US. Students in 
Ethiopia are short on resources and would like to have text books to take home and study. They wrote class notes on small notebooks, and in small letters so that everything could fit. The college's computers were old and few, electricity and internet were intermittent, and the library consisted of outdated books. The US students also found that most Ethiopian faculty only have a Bachelor's degree and little or no real-world experience while their American professors mostly had Ph.D.'s, a lot more experience and are more knowledgeable about all subjects in general.

The American students came away from this experience with a new appreciation of how very rich even the least of the California State university campuses are.

Near the end of the visit, the American students took the young male teacher who had been their primary guide to lunch despite the American's status of being the guests. Generally guests are not allowed to pay in Ethiopia and the American students went to some lengths to insist on paying in the American way. On a later day he took them to his home, which was humble and had no running water. His family made them welcome and served food and drink. Upon leaving, the American students insisted on leaving money despite the obvious embarrassment of the Ethiopian family.

The student's actions, words, and writings, clearly showed attitudes of intrinsically American self-reference-criteria, especially at the beginning of the experience. The student's purely American outlook and concerns, such as in regard to gender equality issues, were clearly on display early on. Subsequent exposure to the reality of Ethiopian life taught them the limitations of transferring American values and bias's to non-related cultures although they could not actually escape the bias' of US culture. They did find that whatever social issues currently exist in Ethiopian culture have little or nothing to do with American culture and this may have been the greatest part of the cultural learning that took place.

\section{CONCLUSIONS}

All three of these international experiences provided at least some cross-cultural experience and learning. However, the type and depth of this gained knowledge differed greatly. The Mexico experience is certainly of a common type that is quick and low-cost but offered minimum opportunities for cross-cultural learning. Classroom lectures and factory visits, though, are not especially conducive to hands-on cross-cultural learning. Observations and encounters during the student's after-hours excursions were not analyzed or even discussed in terms of Mexican culture. With thirty American students to interact with each other, there was little need or opportunity to interact with Mexican nationals. This is in contradiction to Orvis and Wajda (2008), and others, who advocate study abroad that goes beyond classroom teaching.

The international business-planning student groups in Germany were an excellent hands-on work experience that provided immediate and on-going lessons in working across cultures. Williams (2005) states that study-abroad programs which combine direct crosscultural interaction will maximize intercultural communication learning. However, working with three or four different cultures simultaneously might make it difficult to obtain solid knowledge on any one foreign culture. The failing of this study-abroad visit was in the handling of unplanned critical incidents. Brice (2012), Brislin and Yoshida (1994) all found that real-life cultural immersion incidents, with faculty directed analysis, is vitally important in international student programs. The unplanned critical incidents, if properly used as learning examples, could have given the American students great insight into German culture as well as their own. For it is only when seeing the student's own culture through the eyes of foreigners that they can clearly see what makes it different; although not always in a good 
way.

The Ethiopian experience was constructed so as to make it impossible to not be immersed in the foreign culture with many one-to-one interactions in line with Rohrlich and Martin (1991), who found that students who interacted on a one-to-one basis with foreign nationals obtained the greatest gains in cross-cultural knowledge. Working with host nationals on a practical project, combined with full immersion, along with an inability to retreat among a large group of other Americans, created the means for maximum cross-cultural learning. Expert faculty and Hofstede's (1991) textbook on culture were always available to assist in analyzing the constant surprises they faced; which gave critical incidents context, per Brice (2012), Brislin and Yoshida (1994). This learning was reflected in a transformational change in beliefs and attitudes towards Ethiopia, and possibly all other third-world countries, as evidenced in the student's writings. 


\section{REFERENCES}

Albers-Miller, N., Prenshaw, P. and Straughan, R. (1999). Student perceptions of study abroad programs: A survey of US colleges and universities, Marketing Education Review. 9(1), 29-36.

Bhandari, R. and Chow, P. (2007). Open doors 2007: Report on international educational exchange. New York: Institute of International Education.

Brice, W. (2012). American students in Germany: A pedagogy of critical incidents. Global Education Journal, 2012(2): 51-58.

Brislin, R., and Yoshida, T. (1994). Improving intercultural interactions, modules for cross-cultural training programs. Thousand Oaks, Ca.: Sage.

Clarke, I., Flaherty, T., Wright, N., and McMillen, R. (2009). Student intercultural proficiency from study abroad programs, Journal of Marketing Education, 31(2), 173-181.

Erffmeyer, R. and Al-Khatib, J. (1997). Students' study abroad experiences: Gaijin in Japan, Marketing Education Review. 7(1), 63-69.

Gillespie, J. (2002). Colleges need better ways to assess study-abroad programs, The Chronicle of Higher Education, 48(43), B20.

Hofstede, G. (1980). Culture's consequences: International differences in work-related values. Beverly Hills, Ca.: Sage Publications.

Hofstede, G. (1991). Cultures and organizations: Software of the mind. London, UK.: McGraw-Hill.

Hofstede, G. (2001). Culture's consequences: Comparing values, behaviors, institutions, and organizations across nations, $2^{\text {nd }} E d$. Beverly Hills, Ca.: Sage Publications.

Holland, K. and Kedia, B. (2003). Internationalizing business students through the study abroad experience: Opportunities and challenges, Advances in International Marketing. 13, 115-139.

Ingraham, E. (2003). Study abroad: Perspectives and experiences from business schools, Advances in International Marketing. 13, 1-21.

Orvis, B. and Wajda, T. (2008). Business student travel abroad: Clarifying definitions and measures of value and assessment, Marketing Management Association Fall Educators' Conference - 2008. Louisville, KY.

Rohrlich, B. and Martin, J. (1991). Host country and re-entry adjustment sojourners, International Journal of Intercultural Relations. 15, 163-182.

Schuster, C., Zimmerman, R., Schertzer, C., and Beamish, P. (1998). Assessing the impact of executive MBA international travel courses, Journal of Marketing Education. 20(2), 121-132.

Webb, J. (2007). Death to US: Anti-Americanism examined. BBC News, retrieved from www.news.bbc.co.uk.

Williams, T. (2005). Exploring the impact of study abroad on students' intercultural communications skills: Adaptability and sensitivity, Journal of Studies in International Education. 9(4), 356-371. 